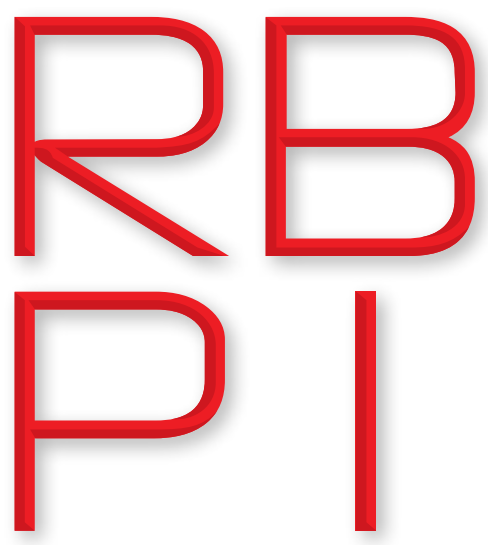

Revista Brasileira de Política Internacional ISSN 1983-3121

http://www.scielo.br/rbpi

\section{Susanne Gratius}

Universidad Autónoma de Madrid, Facultad de Derecho, Madrid, Spain (susanne.gratius@uam.es).

\section{Copyright:}

- This is an open-access article distributed under the terms of a Creative Commons Attribution License, which permits unrestricted use, distribution, and reproduction in any medium, provided that the original author and source are credited.

- Este é um artigo publicado em acesso aberto e distribuído sob os termos da Licença de Atribuição Creative Commons, que permite uso irrestrito, distribuição e reprodução em qualquer meio, desde que o autor e a fonte originais sejam creditados.

\section{Brazil and the European Union: from liberal inter-regionalism to realist bilateralism}

DOI: http://dx.doi.org/10.1590/0034-7329201800103

Rev. Bras. Polít. Int., 61(1): e003, 2018

\section{Abstract}

Brazil-European Union relations punch below their weight. Cooperation takes place at three levels: relations with European Union (EU) member states, Brazil's partnership with Brussels, and EU-MERCOSUR negotiations. This multilevel governance contrasts with poor results: there is no free trade agreement, development cooperation became irrelevant, and international positions rarely converge. The article explores the reasons for the underperformance by comparing foreign policy shifts in Brazil and the $E U$, and analyzing multilevel governance in selected sectors of cooperation. It is based on four assumptions: multilevel relations are uncoordinated, idealist inter-regionalism doesn't work, and crisis-driven, liberal realist foreign policies in Brazil and the EU facilitate bilateralism.

Keywords: Brazil; European Union; regionalism; interregionalism; foreign policy.

Received: August 23, 2017 Accepted: October 23, 2017

\section{Introduction}

S ince 1960, when they established diplomatic contacts, Brazil and the European Union (EU) have steadily upgraded their relations until the signature of a strategic partnership in 2007. Today, Brazil-EU cooperation moves between liberal interregionalism - based on two integrated blocs - as an obstacle, and realist bilateralism, as an opportunity for progress. Multitier cooperation includes EU-CELAC Summits (Comunidade de Estados Latino-Americanos e Caribenhos) and EU-MERCOSUR negotiations, but also the EU-Brazil partnership and special relations with Spain and Portugal. The umbrella of the EU-Brazil "Strategic Partnership" covers three competing institutional levels: 1) EU-MERCOSUR inter-regionalism, 2) cooperation between Brazil and Brussels, and 3) bilateral Strategic Partnerships with EU member states. 
Ten years after defining Brazil as a strategic partner of the EU, singled out by its regional power and BRICS' membership, relations lack clear results (Ferreira-Pereira 2016). A free trade agreement remains lost in EU-MERCOSUR negotiations, and Brazil hasn't even explored a bilateral deal with Brussels; development cooperation isn't relevant; and Brasilia's international positions rarely converge with those of the EU. The last exclusive bilateral summit (outside the EU-CELAC framework) took place in February 2014. Following Putnam's (1988) two-level-game (1988), weak Brazil-EU relations are the consequences of severe domestic crisis that provoked foreign policy shifts.

Brazil's deep political, moral, social, and economic crisis and its consequent global decline (Cervo and Lessa 2014) undermine its credibility as an emerging power and a strategic partner of the EU. The unpopular government of Michel Temer - who replaced Dilma Rousseff after her impeachment on 31 August 2016 and managed, one year later, to escape from being investigated of corruption ${ }^{1}-$ will not solve the critical situation of the country. Organisation for Economic Co-operation and Development (OECD) Data confirm that recession reached $-3.4 \%$ in 2016, inflation rate rose $8 \%$, unemployment rose to $11.8 \%$ and poverty rates increased. Large corruption scandals of the Brazilian giants Petrobras and Odebrecht further undermined Brazil's domestic performance and international reputation. In foreign policy, under the conservative Temer government, south-south relationships prioritized by the Partido dos Trabalhadores (PT) lost weight, while traditional partners like the EU and even the United States under Trump rank, again were high on Brazil's external agenda focused on new economic partnerships.

The EU is not in a good shape either. Several terrorist attacks threaten the EU's future as a normative power by strengthening a protectionist security community, the victory of nationalists in the popular referendum on the British membership in the EU in 2016, the refugee crisis, the rise of right-wing political parties, and modest growth rates created additional problems for an already paralyzed EU unable to advance towards a real economic and political Union. Similar to Brazil, domestic priorities dominate the political agenda of the European Union, and there is little room for an upgrading of foreign policy, despite the approval of the EU's Global Strategy in June 2016 and the redefinition of its role in the world (Missiroli 2015). Gradual institutional progress towards a united Europe speaking with one voice is counterbalanced by the rise of Euro-skepticism and European disintegration (Berman 2012).

Since 1999, Brazil-EU relations have been determined by liberal inter-regionalism aimed at "managing increasingly complex global interdependences" (Hänggi, 2000) and promoting blocs of states. Although EU-MERCOSUR negotiations on an association agreement including free trade are going nowhere, both partners maintain the bloc-to-bloc format assuming the costs of a non-agreement. The EU wants to maintain its inter-regional foreign policy doctrine aimed at promoting its integration process to the South. Brazil's reluctance to drop out of MERCOSUR and inter-regionalism has been motivated by the risk of a conflict with Argentina, its strategic

1 On 2 August 2017, at the House of Representatives, Michel Temer was supported by 263 against 172 deputies, who decided not to allow investigations of corruptions against the President. 
partner in the region. However, the lack of a free trade agreement and the high number of strategic partnerships with European countries ${ }^{2}$ (Costa Vaz 2014) evidence a shift towards realist bilateralism in EU-Brazil cooperation and a failure of North-South inter-regional governance as the result of poor regional integration in Latin America (A. Malamud 2013) and the EU's existential crisis (European Commission and European External Action Service 2016).

Why do both partners prioritize "form over function", if bilateralism is a more efficient formula for advancing EU-Brazil relations? From a Brazilian perspective, bilateralism and a horizontal dialogue with the EU represent the recognition of its regional and global leadership role, while inter-regionalism rather suggests an uneven power balance between Brazil and the other four MERCOSUR member states, Argentina, Paraguay, and Uruguay. Moreover, a free trade agreement would be easier to negotiate separately from the rest of MERCOSUR and further up-grade Brazil as a strategic partner of the EU. To single out Brazil by a special bilateral relationship is also an advantage for the EU. First, because of Brazil's leadership position in MERCOSUR, second as a better formula for trade negotiations, and, third, because of its global upgrading and role in the powerful BRICS group. From this perspective, it is highly irrational that EU-MERCOSUR negotiations haven't been replaced by a Brussels-Brasilia format and closer bilateral cooperation on other topics.

The article explores the reasons for stagnation in relations in the period 2007-2017, compares foreign policy shifts in Brazil and in the EU, and evaluates the efficiency of multilevel governance (interregional, transregional, pure and hybrid bilateralism) in different sectors (Table 1). It is based on three assumptions. First, multilevel relations are uncoordinated. Second, liberal inter-regionalism (EU-MERCOSUR) constitutes an obstacle for relations. Third, more realist foreign policies favor pure (Brazil-EU member states) and hybrid bilateralism (Brazil-Brussels). The first section explains Brazil's economic and political decline and the EU's deep crisis as important reasons for "liberal realism". A second part evaluates the performance of key issues in relations (trade, development, security, and climate change) at different levels. Finally, connecting academic debates on interregionalism and foreign policy, the author affirms that bilateral progress in EU-Brazil relations is more likely than inter-regional results.

\section{Two actors in crisis: an uncertain transformation between Liberalism and Realism}

Brazil and the EU have much in common: although in different leagues ${ }^{3}$, they are global economic powers, they share a strong multilateral vocation, defend the same values (human rights, peace, democracy, integration), and both belong to the West (Steiner et al. 2014). Their

2 Half of Brazil's 22 Strategic Partnerships are with European countries: one with Brussels and nine with EU member states Finland, France, Germany, Italy, Portugal, Spain, Sweden and the UK (plus Norway, Finland and Switzerland).

3 In 2016, the EU was the second and Brazil the tenth largest economy of the world. 
international profile is based on soft or civilian power (Maull, 1990) opposed to United States (US) hard power in the case of Brazil, and to Russia's military threat in relation to the EU. Brazil and the EU are emerging foreign policy actors: Brazil because of its ambivalent status between a middle power and a global power (Hurrell 2006), the EU because of the mix between supranational and national foreign policy.

Both address the challenge of solving deep internal crisis that diminishes prospects for cooperation, but also offer the opportunity to revise the format and agenda of a relationship with poor results. They also share the foreign policy preference for "Realist Liberalism" or "Liberal Realism"- defined as a shifting combination between self-interests, security, and power administration on the one hand, and multilateral commitments based on liberal principles and values, on the other. Or, according to Ikenberry and Kupchan $(2004,38)$, "the mix between power and liberal internationalism".

\section{Brazil's domestic interests and its return to the liberal Western Alliance}

The impeachment of Dilma Rousseff and the transfer of power from the PT to the Partido do Movimento Democrático Brasileiro (PMDB) member President Michel Temer ended a foreign policy era, characterized by a radical shift from the Western Alliance to the Global South. Without abandoning economic interests in the BRICS, the Temer Government represents a return to the "West" - a diffuse historic concept of liberal ideas (Stuenkel 2011) - by distancing itself from Lula's autonomous foreign policy oriented towards MERCOSUR and Union of South American Nations (UNASUR) in the region, and the BRICS at the international level. One clear signal is Brazil's request for membership in the OECD that "essentially symbolizes the West" and "was rejected by the government (of Lula) for ideological reasons (Stuenkel 2011).

This occurs in a moment of the deepest crisis of the liberal Western order (Nye 2017) questioned by the Trump Administration in the United States abroad, and a severe crisis at home. Economic decline contributed to the political crisis. The deep recession of $-3,4 \%$ in 2016 , an inflation rate of $8 \%$ and rising unemployment reversed the positive trend towards poverty reduction and per capita income, which fell from 13.200 in 2011 to 8.600 dollar in 2015. The social decline altered Brazil's strong performance as an emerging global player and a successful developmental state (Tepperman 2016).

Under Lula (2003-2011) and, less visible, during the Presidency of Dilma Rousseff (2011-2016) who "clearly demonstrated little interest in foreign affairs" (Saraiva 2017, 10), south-south cooperation with new global powers replaced the country's traditional identity as a Western ally. It introduced a new paradigm of Brazil as a leading voice of the global South, soft balancing US power (Hurrell 2006) and EU influence (Gratius 2012) through alternative alliances and an independent foreign policy. The narrative of Brazil as an emerging regional and global power was strengthened by its active role in the BRICS and a closer political and economic alignment with China. 
This radical shift under the PT governments generated an ideological debate in Brazil's foreign policy between developmental South-South autonomists and North-South neoliberals (Saraiva, 2012). Brazil's business community remains divided between liberalists and protectionists: while the powerful business association Federação das Indústrias do Estado de São Paulo (FIESP) in Sao Paulo strongly supports liberalizing the Brazilian economy, the Confederação Nacional das Induistrias (CNI, national confederation of industries) rather defends the opposite.

Michel Temer represents the partial restoration of the "ancient regime" of North-South liberals after the impeachment against Dilma Rousseff whose "reputation suffered irreparable damage" (Mello and Spektor 2016, 103). Temer's government will be transitional until presidential elections in October 2018, and could even end earlier, as the President himself is involved in different corruption scandals. It introduced major policy changes, among others the decision to freeze the budget over the next 20 years, including social expenditures and state control over the economy.

The discourse of Temer's first Foreign Minister José Serra (Partido da Social Democracia Brasileira - PSDB) suggested a come-back of Brazil's traditional foreign policy of Western alignment and "liberal realism" between values and interests. In an early speech, Serra (2016) announced his aim to reduce the "strong PT's influence under the Presidencies of Lula and Dilma" by a foreign policy based on ten principles:

1) de-ideologization and transparency,

2) defense of democracy and human rights,

3) leadership on climate change and clean energies,

4) constructive engagement in regional and international organizations,

5) bilateral trade deals,

6) export promotion,

7) recovery of liberal principles in relations with Argentina and MERCOSUR,

8) reactivation of economic relations with the United States, Japan and the EU,

9) economic interest based south-south cooperation and,

10) participation of the private sector and foreign investment to modernize Brazil.

Before Trump became President, Serra announced the possibility of signing a free trade deal with the United States (Cárdenas 2016). At his first official visit to Argentina he agreed with the conservative government of President Mauricio Macri a liberal reorientation of MERCOSUR, including the possibility of signing bilateral trade agreements "that prevailed over multilateral deals" (Saraiva and Velasco Júnior 2016, 313). President Temer's participation in the BRICS Summits in 2016 and 2017 was motivated by pragmatic economic interests (China being Brazil's main export market).

Likewise, Serra's successor Aloysio Nunes Ferreira suggested to bring MERCOSUR closer to the Pacific Alliance (Chile, Colombia, Mexico, Peru), and promised to improve economic ties with the EU. This position confirms a discourse of liberal "commercial diplomacy" (Saraiva and Velasco Júnior 2016). At the political front, Brazil's support for the exclusion of Venezuela from MERCOSUR by applying the democracy clause has been another indicator for the return to 
liberal values, combined with traditional realist principles (national sovereignty, protectionism and power aspirations, (Weyland 2016)).

Brazil's foreign policy change responds to a balance between realism (Weyland 2016) and liberalism (Trinkunas 2016): realist national interests (trade, investment, and development) and the search for global and regional power status coincide with liberal values (human rights, peace), an ideological return to the liberal West and liberal economic principles (deregulation and less protectionism). This foreign policy shift from the BRICS focus chosen by Lula in 2003 to one on more traditional partners underlines the predominance of presidential preferences and ideology in Brazilian foreign policy (Stuenkel, 2017), where the influence of the executive branch is still higher than in other policy fields.

If "realist national power and global clout [...] have driven Brazilian foreign policy for more than a century" (Weyland 2016, 157), the Temer government abandoned the search for regional and global power status in favor of opening new markets and global liberalism. Against the exclusive realist approach of Weyland (2016), the latter confirms the liberal tradition in Brazilian foreign policy: "On a range of other principles that also undergird the international order — such as the ban on aggressive war, proliferation of weapons of mass destruction, and support for a global market-based economy - Brazil is largely supportive, and much more so than countries such as China and Russia" (Trinkunas 2016).

However, it is unclear if the foreign policy reorientation under Temer will have any practical consequences until the political crisis in Brazil is resolved by Presidential elections. Similar to Dilma Rousseff's low profile in foreign policy (Ferreira-Pereira 2016), her successor focuses on domestic issues; a trend that has been confirmed by budget cuts and a low international profile.

\section{The EU's existential crisis and a liberal realist Global Strategy}

The EU's survival as the world deepest liberal integration process is endangered by three factors. First, the decision of 51.9\% of British citizens to leave the EU (Molina 2016), a process that is still negotiated and deepened the EU's internal crisis. Second, the rise of right-wing political parties as a reaction to terrorism and the arrival of 1,5 million refugees from fragile states demonstrated the limits of integration and management capacities of the EU (Molina and Gratius 2016). The wave of terrorist attacks in European cities reinforces a security-based fortress EU, more integrated, but less open to the world. Third, the modest economic outlook in most EU member states except from Spain and Portugal - an expected average growth of $1.6 \%$ in 2017 - and social cuts in Southern Europe reduced citizens' support of integration.

The lack of a strong political leadership in the EU and the economic crisis provoked a come-back of nationalist policies and weakened the capacity, role and autonomy of supranational institutions such as the European Commission or the European Parliament (EP). In midst of turmoil, the European External Action Service (EEAS), since 2014 under the leadership of Federica Mogherini, gained in 
autonomy and capacity to manage international crises and to define the external priorities of the EU by the Global Strategy approved in 2016 as the new foreign policy orientation. How to solve the contradiction between its increasing global actorness and the simultaneous rise of nationalism as a response to domestic threats will remain a major challenge for the EU.

The EU's identity as an integration process between liberal inter-governmentalism (Moravcsik 1993) and supranationalism shape its foreign and security policy. After the classical dispute between federalists and state-centrists, the deepening of integration in the 1990s introduced a debate on "multilevel governance" (Marks and Hooghe 1996) that characterizes the EU's distinctive political system. In foreign policy, the EU's dual identity between autonomous institutions and nation-states created a hybrid structure between liberal inter-regionalism on the one hand, and a more realist bilateralism (hybrid with Brussels and pure with EU member states), on the other (Table 1).

Different to other public policies, multilevel governance in foreign policy means the coexistence and decision making between, 1) pooling sovereignty by Europeanization (European Commission and the European External Action Service, EEAS, and the EP), 2) the bilateral level of Member States, 3) the local or regional politics in some areas such as environment or development and 4) the global playground of international organization in certain policy fields. Preferences in these four levels are formulated by officials, non-state actors, and lobbies - a complex process (Moravcsik 1993) that tend to dilute clear foreign policy decisions.

Bendiek $(2011,35)$ sustains that EU foreign policy after the Lisbon Treaty (European Union 2015) and the financial crisis follows an "intergovernmental fragmented structure" that can be explained by Realism as "the proper candidate for theoretical guidance". In the same direction, Chryssogelos $(2016,12)$ observes a "commercialization of EU foreign policy to pursue "national economic gains" after the financial crisis. The EU Global Strategy confirms this change from a normative, value-oriented common foreign and security policy towards a more nation state and interest-driven approach of "liberal realism" (Ayuso and Gratius 2016) that coincides with a similar foreign policy approach in Brazil.

Brussel's traditional normative and ideational power by values and example have been weakened and de-constructed by the revival of patriotism as a response to threats and terrorist attacks in Belgium, France, Germany, the UK and Spain, combined with the massive arrival of refugees from crisis-prone regions. Liberal realism in EU foreign policy is the result of domestic preferences and the influence of national lobbies on inter-governmental negotiations, according to Moravcsik (1993).

The EU's reaction as a fortress, united in the fight against terrorism, but also strengthening borders and sending refugees back to Turkey and other countries with a doubtful human rights record, combined with thousands of deaths in the Mediterranean, damages its image as a soft power promoting development cooperation, dialogue and the promotion of human rights. Common threats and "a nationalism of fear" might push the EU into a "negative" security community as a fortress against the global South. The trade-off between security and human rights undermines the EU's profile of a civilian soft-power and an international norms setter (Tocci 2008). 
The shift towards "liberal realism" in the EU and the poor performance of integration in the South including MERCOSUR weakens inter-regionalism as a European foreign policy branding. Different to the liberal approach, the Global Strategy favors a realist-driven inter-regionalism:

Where possible and when in line with our interests, the EU will support regional organizations [...]. Cooperative regional orders, however, are not created only by organizations. They comprise a mix of bilateral, subregional, regional and interregional relations. They also feature the role of global players interlinked with regionally-owned cooperative efforts" (EU and EEAS 2016, 32).

The latter includes Brazil's role as a regional and global power inserted in MERCOSUR.

The EU's foreign policy shift towards Liberalism and Realism that, depending on the topic, could be translated into "liberal realism" (security) or "realist liberalism" (development), is the result of the two-level game between a stronger nationalism in domestic policies and its outside effects that narrow the win-set for external partners. The trade-off between interests and values diminishes the EU's role as a soft power promoter of integration, democracy, human rights and sustainable development - all those issues that rank high in relations with Brazil. Moreover, the weakening of supranational institutions by the economic crisis, Brexit and the weight of Germany in the EU contributed to the benign neglect of minor partners like Brazil that have never ranked high on the EU's agenda or in the hierarchy of Brussel's top strategic partners.

\section{Multilevel governance and liberal realism in Brazil-EU relations}

The dilemma between "liberal realism", on one side, and multilevel governance, on the other, is not yet solved. Multitier EU-Brazil relations are conditioned by a misconception: As a nation-state Brazil follows a "realist tradition" of diplomacy (Saraiva 2012, 46) focused on bilateralism with individual European countries (mainly France, Germany, Portugal, Spain, and the UK), while the EU represents in several areas of mixed competences (investment, development, security, climate change) a collective supranational actor beyond national interests with a strong liberal approach and diffusing inter-regionalism (Ribeiro-Hoffmann 2016).

Brazilian foreign policy, divided between the search for developmental autonomy under the PT Presidencies 2003-2016 (Saraiva 2012, 48), on the one hand, and liberal realism, on the other, introduces another element of change in relations. According to the ten principles maintained by Minister Nunes Ferreira, liberal realism looks like the preferred option of the Temer government, while the Itamaraty represents both positions. Brazil's recent foreign policy shift from developmentalism to historic "liberal realism" (realist-liberal, according to Merke, $2008^{4}$ ), its re-alignment with the West and

4 Federico Merke (2008) describes the realist-liberalist identity as one of the discourse traditions in Brazil's foreign policy, referring to its "historic vocation as a peaceful state, geopolitically satisfied, ally of the United States and called to occupy a prestigious position in the international system" (own translation). In this vision, Latin America plays a marginal role. 
the shift from soft balancing (Hurrell 2006) to bandwagoning (the West) could open new opportunities for cooperation on global governance with the EU after a long period of stagnation (Saraiva 2017).

From an EU perspective, the Global Strategy, the need for new export niches, combined with Brazil's conservative government and the possible re-launch of MERCOSUR as a less protectionist bloc facilitate negotiations on a free trade deal. This option gains in attraction to the extent that a bilateral Brazil-US trade agreement loses ground during a protectionist Trump Administration which has already dropped out of the Trans Pacific Partnership (TPP), threatens to retire from North American Free Trade Agreement (NAFTA) and blocks negotiations on a Transatlantic Trade and Investment Partnership (TTIP) with the EU. On the other hand, the rise of populist right-wing nationalist governments and opposition forces in France, Germany, Hungary, Italy, or Poland reinforces the trend towards protectionism in agriculture that has been a major obstacle in EU-MERCOSUR negotiations and between Brazil and Brussels.

\section{Multilevel governance in key sectors of Brazil-EU cooperation}

Brazil-EU relations fit into Hänggi's sub-types of inter-regionalism: pure, transnational, and hybrid (Hänggi 2000; Hänggi at al. 2006; Gardini and Malamud 2014; Ribeiro-Hoffmann 2016), but also into hybrid and pure bilateralism. The first level, EU-MERCOSUR relations, represents "pure interregionalism" between two integrated groups of states that ideally speak with one voice. Beyond this top-down approach, the second level relates to Hänggi's category of trans-regionalism and integrates non-state actors. The third level, the Brasilia-Brussels framework, could fit into hybrid inter-regionalism (Ribeiro-Hoffmann 2016) or hybrid bilateralism. The fourth dimension refers to bilateralism between Brazil and ten EU member states (pure bilateralism). The result is a complex scheme of multilevel relations with partly overlapping agendas.

Table 1: EU-Brazil multilevel governance

\begin{tabular}{|c|c|c|c|}
\hline Category & Format & Instruments & Main topics \\
\hline \multicolumn{4}{|l|}{ Inter-regionalism } \\
\hline Pure Interregionalism & EU-MERCOSUR & $\begin{array}{l}\text { EU-MERCOSUR agreement } \\
1995 \text {, trade negotiations }\end{array}$ & $\begin{array}{l}\text { Trade, development, political } \\
\text { dialogue }\end{array}$ \\
\hline Trans-regionalism & $\begin{array}{l}\text { EU-MERCOSUR } \\
\text { Business forum (MEBF), } \\
\text { civil societies }\end{array}$ & $\begin{array}{l}\text { Business meetings since February } \\
\text { 1999, parliamentary sessions, } \\
\text { civil society forum }\end{array}$ & $\begin{array}{l}\text { Trade, investment, } \\
\text { migration, development, etc. }\end{array}$ \\
\hline \multicolumn{4}{|l|}{ Bilateralism } \\
\hline Hybrid bilateralism & $\begin{array}{l}\text { Brazil and the EU } \\
\text { (Brussels, EC) }\end{array}$ & $\begin{array}{l}\text { Strategic Partnership, } 33 \text { sector } \\
\text { dialogues }\end{array}$ & $\begin{array}{l}\text { Energy, climate change, } \\
\text { global issues }\end{array}$ \\
\hline Pure bilateralism & $\begin{array}{l}\text { Brazil and EU member } \\
\text { states }\end{array}$ & $\begin{array}{l}\text { Bilateral treaties, Strategic } \\
\text { Partnerships: summits and } \\
\text { bilateral meetings }\end{array}$ & Everything except from trade \\
\hline
\end{tabular}

Source: Own elaboration based on Hänggi (2000) and Ribeiro-Hoffmann (2016). 
The EU's Strategic Partnerships occur outside inter-regional cooperation schemes with the purpose of singling out certain traditional or emerging powers by strengthening bilateral ties (EC 2007). In this sense, strategic partnerships respond to the realist tradition of an anarchic system of states rather than to the liberal and cosmopolitan approach of inter-regionalism (Ayuso and Gardini, 2015) as Hänggi (2000) suggests.

Brazil-EU relations follow a trend towards bilateralism between the EU and individual Latin American states by signing free trade or other agreements (Chile, Colombia, Cuba, Mexico, and Peru). These cases don't respond to "a greater degree of national adaptation to EU foreign policy norms or 'Europeanization' (Smith 2004, 741), but to the opposite: intergovernmental bilateral patterns clearly prevail over inter-regionalism.

In terms of costs and benefits, trade is the real strategic issue in Brazil-EU relations. In this field, the formulation of preferences in inter-governmental negotiations (Moravcsik 1993, 483) have been a major obstacle to a free trade agreement between the EU and MERCOSUR. Other important sectors ${ }^{5}$ of cooperation, such as investment, development cooperation, security, and climate change, give further evidence of the dominance of bilateralism in relations that respond to interest-driven realism.

\section{Trade: asymmetric, no-go inter-regionalism}

Liberal inter-regionalism has been a brand of the EU and its global promotion of integration rather than an efficient formula for trade negotiations. There are very few exceptions to that rule. One of them are the EU's collective free trade agreements with Central America and the Caribbean, although they respond to the small-states' logic that even the United States followed in order to avoid six and fourteen negotiations with dwarf nations.

EU-Brazil trade relations are shaped by asymmetric interdependence (Womack, 2016): Brazil contributes around 3\% to Brussel's extra-regional trade exchanges, and the EU has a constant share of about $20 \%$ of Brazil's imports and exports and remains its main commercial partner, slightly before China and the US. Until 2014, Brazil ranked ninth in the EU's hierarchy of trade partners. In 2015, it fell back to the 11 th position because of the economic crisis. In trade affairs, the EU acts as a unique actor. Because of its hardliner negotiation position on the two core issues, agriculture, and services, Brazil perceives the EU as a supranational collective actor to be a rather negative partner (Saraiva 2012,46) rather than as an ally. Taking into account economic and developmental asymmetries, in theory, collective MERCOSUR negotiations increase Brazil's bargaining power towards the EU, but two decades of failure dismantle this argument.

5 These issues are the most promising and those that are regularly part of the Brazil-EU agenda and summit declarations. They are also included in the 31 sector dialogues (together with others like the UN, human rights, finances, drugs, disarmament, peace and security, social policies, and energy). 
During the 1990s, MERCOSUR was the EU's key partner in Latin America with which it began an inter-regional negotiation process on an association agreement including free trade. In 1999, when the process was officially launched at the first EU-LAC-Caribbean Summit ${ }^{6}$ in Rio de Janeiro, MERCOSUR offered an attractive platform for EU investment and trade (with a positive balance for Europe). At that time, the EU prioritized inter-regional relations with similar trade blocs and had little interest in fostering bilateral ties with countries in the far South. In 1992, the European Commission signed a first institutional accord with MERCOSUR and three years later an inter-regional cooperation agreement. Later on, both created the EU-MERCOSUR Business Forum and civil society meetings (trans-regionalism).

The bloc's first period (1991-1998) was a full success and integration advanced faster than expected. In 1995, MERCOSUR established itself as a customs union. But the EU's logistical support and initial enthusiasm quickly vanished when Brazil suffered, three years later, a devaluation of the Real. In 2002, the dramatic financial collapse in Argentina paralyzed MERCOSUR and negotiations with the EU for several years. In 2004, both presented their trade offers, but, in the same year they agreed to condition an inter-regional deal to the outcome of the World Trade Organization Doha round (WTO Doha). This attempt to shift from an inter-regional to the global level failed in 2008, among other reasons, because of the disagreement between Brazil and the EU/US on agriculture subsidies and lower tariffs for industrial products.

The obstacles are well known and respond to a realist zero-sum-game: the expected gains of the EU in services and industrial goods are the main losses of MERCOSUR and, vice-versa, the potential benefits of MERCOSUR in agriculture pose the main risk to the EU. The critical EP's Resolution approved in March 2013, in the aftermath of the economic crisis, underlined the powerful opposition (mainly comprising the French agriculture lobby) to a free trade deal with MERCOSUR that could negatively affect a weakened European economy. Against the assumption of the EU as one single trade bloc, domestic lobbies have a strong voice: French farmers, together with agriculture lobbies in other member states blocked major concessions by the EU in negotiations with MERCOSUR, giving further evidence of Moravcsik's (1993) liberal inter-governmentalism of domestic preferences.

Aside from mutual fears and threats, a free trade deal stagnated for other reasons. The EU's formula of bloc-to-bloc negotiations is highly asymmetric. Its counterpart MERCOSUR remains a much less advanced integration process that does not foresee any kind of pooling sovereignty nor supranational institutions. Nearly two decades of unsuccessful negotiations lead to the conclusion that the dialogue formula $1+4$ does not work. Additionally, the European Commission is too powerful compared to the weak national governments of individual MERCOSUR trading partners Argentina, Brazil, Paraguay, and Uruguay. In this sense, asymmetric power positions created negative dynamics (Womack 2016). The lack of a common trade policy in each sector and a large number of exceptions in others give little credibility to MERCOSUR as a bloc or, following

6 Latin America, the Caribbean and the European Union Summit (LAC). 
"pure inter-regionalism”, as an equivalent partner of the EU. Asymmetric inter-regionalism failed, given that in the EU's areas of interests, services, and industries, MERCOSUR does not act as a collective entity but divides into four national policies (M. Vaillant and P. Vaillant 2014).

Spill-over and spill-backs of integration in MERCOSUR depend on unforeseeable presidential shifts and decisions, particularly between the biggest states Argentina and Brazil. Even if both countries agree on a free trade deal with the EU, they have to convince the two smaller states and cannot guarantee continuity in a highly uncertain political context of possible ideological changes in presidency and the strong influence of protectionist lobbies in Argentina and particularly Brazil.

These conditions make a collective, inter-regional agreement highly unlikely and, from an EU perspective, a risky business. On behalf of MERCOSUR, the credibility of the European Commission as an exclusive and liable negotiation partner is undermined by the multi-layer process of decision-making and the strong influence of French, Polish, and other member states' agricultural lobbies whose interests are represented by a protectionist Agriculture Commissioner and the EP. In this sense, not even the EU is able to act as a single player.

The result of this multilevel game of trade negotiations is a non-agreement. Possibly, bilateral EU-Brazil negotiations (hybrid bilateralism) won't change these negative dynamics, but under the current conditions of imbalances regarding power, competences, and partners, a free trade deal between the EU and MERCOSUR seems unlikely. The alternative scenario of a bilateral Brazil-EU free trade agreement has been impossible with an EU trapped in its own inefficient formula of inter-regionalism and Brazil's sensitive relations with Argentina. For these reasons, both keep irrational inter-regionalism and accept the costs of a non-agreement.

\section{Investment: bilateralism prevails but inter-regionalism dominates}

In 2015, Brazil was the third main destination of EU Foreign Direct Investment (FDI) and the first among BRICS and Latin America (European FDI stock in Brazil doubled that of Mexico). The EU - mainly the Netherlands, Spain, the UK, France, and Germany - is Brazil's largest investor in terms of stock (Agência Brasileira de Promoção de Exportaçóes e Investimento 2017): it accounts for more than half and European capital flows tripled from 130 billion Euros in 2000 to 387 billion in 2014 .

With a share over 15\% of total FDI in Brazil, Spain is Brazil's main European investor and ranks third in total Brazilian investment flows (C. Malamud 2014, 70). Spanish banks and companies such as Grupo Santander, BBVA, Repsol or Telefónica invested and opened businesses in Brazil which became the main destiny of Spanish investment in Latin America. France, Brazil's fifth largest investor in 2014, and Germany, with an FDI stock of 23,2 billion USD in 2013, also have important economic interests in Brazil. According to the Brazilian Foreign Ministry, 1600 German companies account for 8-10\% of Brazil's GDP, and "Sao Paulo is the largest German industrial city" (Ministério das Relaçôes Exteriores [n.d.]). 
Regarding investment, the EC does not have exclusive negotiation competence, but needs a positive feed-back of member states and takes into account national investment regimes. According to the United Nations Conference on Trade and Development (UNCTAD), Brazil signed eleven of its bilateral Investment treaties with European partners (Belgium, Denmark, Finland, France, Germany, Italy, Luxemburg, the Netherlands, Portugal, Switzerland, and the UK). These constitute the bases for a collective legislative that should include Spain as one of the countries that has not yet signed an investment protection agreement with Brazil (C. Malamud, 2014, 80).

The absence of a collective investment regime in the EU and in MERCOSUR is a further argument for bilateralism. Although investment is the most important incentive for signing an EU-MERCOSUR agreement, it is also one of its major obstacles. MERCOSUR has no common investment regime and capital flows are still national competences. The Lisbon Treaty increased the EU's competences in investment in order to facilitate economic agreements with third countries and further harmonize national investment policies. Despite this, core competences on investment are still assumed by EU member states' regulatory functions and large multinational companies. From a foreign policy perspective of liberal realism it makes little sense to wait for an inter-regional decision, if bilateral negotiations on investment could advance further.

\section{Development Cooperation: mixed competences and horizontal relations}

Since 2015, in midst of a severe political, economic and social crisis, Brazil disappeared from the list of EU bilateral aid beneficiaries at a time when it began to reduce its engagement as an emerging donor (Ayllón Pino 2015). The main argument for exclusion was Brazil's relatively high level of development (the ninth largest economy), and the concentration of EU aid flows to less developed countries like Bolivia, Haiti, Honduras, or Paraguay.

The EU divides relations with MERCOSUR into a bloc of three high developed countries (Argentina, Brazil, Uruguay) and one or two partners (Paraguay and eventually Bolivia) that are still receiving high aid flows. The policy of EU member states is similar, even though Spain still maintains development assistance with middle-income countries, and also Germany continues to support sustainable development in Brazil. As a middle-income country, Brazil is in transition towards knowledge-based triangle cooperation with the EC and its member states $^{7}$ (Ayllón Pino 2015).

During the economic boom under President Lula da Silva, Brazil itself became a donor under the label of south-south cooperation (Ayllón Pino 2015) and through the institutional frame of the development agency ABC. It is the main contributor to MERCOSUR's social cohesion fund Fundo para a Convergência Estrutural do MERCOSUL (FOCEM) and spent, in 2012, more than US\$360 million on development assistance to poor partners in the South (C. Malamud 2014, 52).

7 Brazil signed agreements on triangle cooperation with the EU, Germany, Spain and the UK. 
Brazilian development cooperation concentrates on technical capacity-building, and recipients are divided between African and Latin American partners. According to the Brazilian development agency $\mathrm{ABC}$, the number of projects executed (783) peaked in 2011, whereas it declined in 2013 and 2014 by half (385 projects).

According to the Temer government, it will maintain Southern partnerships, but from a realist economic perspective of benefits for Brazil. Consequently, the Brazil-EU developmental partnership, including triangle cooperation in Africa during the PT governments, might suffer a set-back, as well as Brazilian initiatives to reduce poverty and inequity, an area where both partners reached a great level of convergence (Gratius 2011).

Economic constraints and the minority position regarding developmentalists in Itamaraty limit prospects for south-south cooperation. The mixed competences of the EC and EU member states in development cooperation and the division of MERCOSUR countries between donors and recipients also reduces the prospects for a common developmental regime in a hypothetical agreement to very general commitments that, again, could better be specified in a more sophisticated bilateral deal.

\section{Security as a national and bilateral concern}

Security cooperation is a clear added value of the Strategic Partnership between the EU and Brazil and its 33 dialogue forums on bilateral issues. Security can be defined by the double edge of classical defense against external threats (terrorism and conflicts) and domestic problems (drugs and public insecurity). A concrete result of cooperation on security was the signing of an agreement between Brazil and the European Atom Agency Euratom.

EU-Brazil cooperation in this field dates back to the 1990 s, when both sides established a regular security dialogue in Rio de Janeiro on military affairs, regional and global conflict resolution. Since 2007, the fight against international terrorism and drugs-trafficking dominate the agenda on security. The reluctance of Brazil to accept international interference in domestic affairs has been an obstacle to further cooperation on the country's internal public security challenges.

Security is still a primary national concern and bilateral patterns of cooperation prevail. France has become an important supplier of military equipment and a real strategic partner of Brazil on drug cooperation and national defense (Costa Vaz, 2014, 16). Among others, the UK and its development agency DFID participated in police reform and training in Rio de Janeiro to combat drugs trafficking and insecurity.

There has been much less coordination between Brazil and the EU on international conflicts during the PT governments (Saraiva 2017), when Brazil aligned with the BRICS bloc (Gratius and Grevi 2013). One example was Brazil's failed initiative to advance nuclear negotiations with its former ally Iran in 2010 or the failed proposal to introduce the concept of "Responsibility while protecting" into the UN (Stuenkel, 2014). Under the interim Presidency of Temer, Brazil 
changed its south-south focus on international conflicts and returned to a closer stance with the EUs. In security affairs, "dual bilateralism" (hybrid and pure) determines relations.

\section{Sustainable development and climate change: bilateral and global governance}

In Latin America, Brazil (under the PT governments) has been the EU's closest partner on climate change negotiations towards the Paris Agreement signed in December 2015. Brazil-EU cooperation on sustainable development and climate change bypasses the EU-MERCOSUR agenda that also includes environmental issues. Compared to the trade knot, cooperation on environment and climate change is the real success story in EU-Brazil relations that proves the advantages of bilateralism over inter-regionalism. Sustainable development and climate change illustrate that "dual bilateralism" generate positive outcomes if both partners agree on the basics. In this case, the shared commitment to multilateralism and global governance focused on similar environmental goals clearly prevailed over national interests. This liberal approach contrasts with an economic interests driven agenda of the Temer government, reluctant to maintain the policy against deforestation and less committed to climate change.

Brasilia-Brussels climate change dialogue was accompanied by nation-states coordination. A common declaration (Brazil-German Declaration 2015) adopted by former President Dilma Rousseff and Chancellor Angela Merkel reinforced the Brazilian-German strategic partnership and an already close cooperation on climate change. The previous bilateral consensus had a positive impact on a shared Brazil-EU position during climate change negotiations in Paris. At the bilateral level, deforestation, the Amazon fund, and the protection of indigenous areas dominated the bilateral agenda under Rousseff and Chancellor Angela Merkel.

In Paris, Brazil and the EU integrated the same group pushing for a successful conference and a binding commitment on climate change policies until 2030. The global reach was complemented by national commitments to reduce deforestation in the case of Brazil and by the EU's agreement to reduce greenhouse gas emissions (GHG) by another $40 \%$ from today's level of emissions until 2030. Germany has a great interest in reducing deforestation in Brazil, among others, by its contribution to the Amazon fund.

Climate change is an example of the complexity of a multilateral foreign policy, where different national policies (environment, economic, foreign) are strongly influenced by non-governmental actors, regional regimes, and international agreements. Climate change and other transnational challenges as a consequence of globalization force governments to pool national sovereignty and to multilateralize foreign policies. Even though international organizations still depend on the decisions of national governments, the formulation of national and global preferences increasingly also depends on domestic lobbies and international alliances. Climate change and sustainable development as a primary global concern of both Brazil and the EU is also a key issue for a 
bilateral coordination at the global stage. In this area, inter-regionalism is no option, given that there is little foreign policy coordination within MERCOSUR.

\section{Conclusion: bilateralism as the preferred option in EU-Brazil relations}

Brazil-EU relations represent a puzzle between EU-MERCOSUR relations, the Brazil-EU Strategic Partnership, and bilateral cooperation with individual Strategic Partners. Each of the bodies held separate summits and define issues and action plans without any type of coordination or convergence. A clear overlap of agendas and outcomes (see Tables 2 and 3) prove that all these levels of relations lack cohesion. The mutual preference of "form over function" diminishes efficiency given that hybrid and pure bilateralism would better serve Brazilian and EU interests on the trade, development, security, and environmental agenda.

The analysis of selected sector policies in Brazil-EU relations confirm a preference for pragmatic realist bilateralism over liberal inter-regionalism: trade (exclusive supranational EU competences and inter-regional level), investment (supranational and national levels), development (supranational, local and national levels), security (national level), and climate change (all levels). The failure of inter-regional trade negotiations contrasts with positive results in Brazil-member states relations and strategic relations with Brussels.

Thus, to advance bilateral relations, neglecting the MERCOSUR dimension seems to be a more viable option than pushing for inter-regionalism that has not proven to be successful in any of the five areas analyzed (trade, investment, development, security, and environment). Against these arguments, both partners maintain the inter-regional format as a concession to their collective identities that weights more than a result-oriented negotiation process.

Brazil's state-centered foreign policy (Saraiva 2017) coexists with the EU's "multi-level governance of foreign policy" (Smith 2004, 741). The absence of visible progress in Brazil-EU

Table 2: Multilevel Brazil-EU relations

\begin{tabular}{|c|c|c|c|c|}
\hline & Inter-regionalism & $\begin{array}{c}\text { Bilateralism } \\
\text { Brussels }\end{array}$ & $\begin{array}{l}\text { Bilateralism EU } \\
\text { Member States }\end{array}$ & Global Governance \\
\hline Trade & $\begin{array}{l}\text { Strong and exclusive } \\
\text { (but no progress) }\end{array}$ & Non issue & No voice & $\begin{array}{l}\text { WTO: weak, dissent (trade } \\
\text { subsidies, tariffs) }\end{array}$ \\
\hline Investment & Some competences & - & Strong competences & None, AMI failed \\
\hline Development & - & - & - & $\begin{array}{l}\text { UN yes, DAC-OECD no } \\
\text { (Brazil is not a member) }\end{array}$ \\
\hline Security & Not included & $\begin{array}{l}\text { Important } \\
\text { issue }\end{array}$ & Important issue (France) & $\begin{array}{l}\mathrm{UN} \text { : some coordination } \\
\text { and dialogue Brazil-Brusels }\end{array}$ \\
\hline $\begin{array}{l}\text { Environment } \\
\text { and Climate } \\
\text { Change }\end{array}$ & $\begin{array}{l}\text { Relevant for trade } \\
\text { negotiations }\end{array}$ & $\begin{array}{l}\text { Important } \\
\text { issue }\end{array}$ & $\begin{array}{c}\text { Strong Brazilian-German } \\
\text { Partnership }\end{array}$ & $\begin{array}{l}\text { Yes, strong, Paris } \\
\text { Agreement, convergence }\end{array}$ \\
\hline
\end{tabular}

Source: Own elaboration (2017). 
Table 3: Strategic Partnerships Brazil-EU

\begin{tabular}{|c|c|c|c|}
\hline SP & Date & Content & $\begin{array}{c}\text { Shared agenda/ } \\
\text { overlap }\end{array}$ \\
\hline EU-Brazil & $\begin{array}{c}2007 \\
\text { (Barroso-Lula) }\end{array}$ & 30 sector dialogues, irregular summits & \multirow{11}{*}{$\begin{array}{c}\text { Education } \\
\text { C \& T } \\
\text { development } \\
\text { cooperation, } \\
\text { environment + } \\
\text { climate }\end{array}$} \\
\hline Finland & & $\mathrm{C} \& \mathrm{~T}$, innovation, support of a permanent UNSC seat of Brazil & \\
\hline France & $\begin{array}{c}2006 \\
\text { (Lula/Chirac) }\end{array}$ & $\begin{array}{l}\text { AP 2008: GG, trade and economic relations, defense, nuclear } \\
\text { energy, culture, education, migration, C\&T, Africa, support } \\
\text { of a permanent UNSC membership }\end{array}$ & \\
\hline Germany & 2010 & $\begin{array}{l}\text { Environment and Climate change, trade and economic } \\
\text { relations, development, trilateral cooperation }\end{array}$ & \\
\hline Italy & - & Migration, tourism, Embraer, trilateral cooperation & \\
\hline Portugal & $2004 ?$ & $\begin{array}{l}\text { Culture, language - Lusophone countries, trilateral } \\
\text { cooperation, annual summits }\end{array}$ & \\
\hline Spain & 2003 & $\begin{array}{l}\text { Investment }\left(2^{\text {nd }} \text { investor }\right) \text {, trade and economics, Science } \\
\text { without Borders, scholarships, C\&T, culture, Iberoamerican } \\
\text { Community, trilateral cooperation, security and defense }\end{array}$ & \\
\hline Sweden & 2008 & $\begin{array}{l}\mathrm{AP}^{*} \text { : regular political dialogue, trade and investment, } \\
\text { bioenergy, environment, } \mathrm{C} \& \mathrm{~T} \text {, culture, education }\end{array}$ & \\
\hline $\begin{array}{l}\text { United } \\
\text { Kingdom }\end{array}$ & $\begin{array}{c}2012 \\
(\text { Strategic } \\
\text { Dialogue } \\
\text { Brazil-UK) }\end{array}$ & Supportive of Brazil's permanent UNSC seat & \\
\hline Norway & - & - & \\
\hline Switzerland & 2008 & Strategic Partnership plan & \\
\hline
\end{tabular}

Source: Own elaboration (2017).

${ }^{*} \mathrm{AP}=$ Action Plan

relations in the last decade can partly be attributed to this type of multi-level governance of foreign policy as obstacle for decision-making and convergence. The EU represents a unique multi-level foreign policy model by combining classic national instruments with supranational trade negotiations of the European Commission, in its relations with Brazil, but the combination of bilateralism and inter-regionalism lacks a coherent strategic, result-oriented approach.

Consequently, Brazil has to deal with a fragmented EU foreign policy of different actors with supranational ambitions and national realities. This won't be a problem, if the EU defines clear competences at each level, but these remain uncoordinated. This lack of strategic thinking has to do with internal power games between the different levels of foreign policy governance (Smith 2004) and the problems of defining collective strategic priorities beyond the EU's immediate neighborhood in its East and Southern borders.

Brazil's foreign policy shift from Lula's "multi-vector approach" (Edler and Lanzarou, 2014) of south-south cooperation to the traditional Western partnership offers another argument for bilateralism. The ideological realignment toward liberal realism in EU-Brazil relations makes a bilateral trade deal more likely. Moreover, the search for economic opportunities and export promotion beyond China and the US is an incentive for mutual trade concessions. During the 
Trump Administration, reluctant to enter into trade negotiations with Latin American partners, the EU could recover its traditional role as a "counterweight" to the United States (Saraiva 2012, 54).

But mutual uncertainties create serious doubts about the likelihood of closer ties. First, Brazil's low level foreign policy under Temer hasn't focused on its main economic partner, the EU. Second, the EU's Global Strategy does not include any hint on the future of relations with Brazil, considered as a second-tier power in EU's geo-political and geo-economic relations. Third, the economic recession in Brazil, the crisis of governance and Temer's bad image by corruption scandals conspire against a clearer commitment of the EU in Brazil. Nonetheless, taking into account that the EU remains a regional rather than a global actor, its relationship with Brazil and Latin America represents an interesting test-case for its future as a global power.

Brazil-EU Strategic Partnerships represent an important instrument for bilateral convergence, but they need cohesion, coordination, and strategic orientation. Eleven of those relationships, one with Brussels and another ten with EU member states confirm close ties between Brazil and Europe, driven by a balance between common values and interests. The complex and dense pattern of relations helped to increase mutual understanding and confidence, but did not create a strategic relationship beyond the formal diplomacy of summits and intergovernmental coordination.

"Dual bilateralism" (pure and hybrid) is more effective than the pure inter-regionalism that denies asymmetries (in terms of negotiation capacity, interests, and development) between two highly unbalanced trade blocs with clear leaders: Germany in the EU and of Brazil in MERCOSUR. From a liberal realist perspective, a Brazil-EU trade deal with a leading voice of these two countries could work better than inter-regionalism (Gratius 2011). Pure bilateralism looks more promising than complex EU-Brussels relations: "as to the objective of fostering inter-regionalism, strategic partnerships have been rather inefficient [...] with Germany and Brazil as well as France and Brazil outstanding examples of "effective bilateralism" (Costa Vaz 2014, 15-16).

This international scenario brings Brazil closer to the EU. In midst of political turmoil in Brazil and in the EU, there are three indicators for a revitalization of relations. First, the government of Michel Temer and its close relationship with the private sector might push for trade liberalization and less state interventionism in the economy. Second, China's role as the main export market of Brazilian primary products reduced the traditional conflict over the EU's agricultural subsidies. Third, an expected foreign policy change in Brazil away from the BRICS and in favor of a stronger partnership with the North could create a new moment for EU-Brazil relations.

Nonetheless, there are also arguments against the revitalization scenario. The lack of mutual strategic priorities and the concentration on domestic concerns diminish the prospects for visible progress in relations, as well as the severe crisis in Brazil, together with relative economic stagnation and protectionism in the Euro zone. Presidential elections in 2018 in Brazil and the identity crisis of European integration pose additional uncertainties in a relationship that promised much but delivered less than expected. For all those reasons, the Brazil-EU relationship might continue to perform below its potential and weight in the near future, but for sure "dual bilateralism" is more efficient than interregionalism. 


\section{References}

Agência Brasileira de Promoção de Exportaçóes e Investimento - APEX-Brazil. Brazil European Union Bilateral Investments Map. Brasília, DF: APEX, 2017.

Ayllón Pino, B. "La Cooperación Sur-Sur en América Latina y Caribe. De una época dorada a una fase incierta." Anuario de la Integración Regional de América Latina y el Gran Caribe, no. 11 (2015): 134-70.

Ayuso, A., and L. Gardini, EU-Latin America and Caribbean Inter-regional relations: complexity and change. Atlantic Future Working Paper 24. Barcelona, 2015. http://www. atlanticfuture.eu/files/1530-LA-EU.pdf

Ayuso, A., and S. Gratius. "América Latina y Europa: ¿repetir o reinventar un ciclo?" Pensamiento Propio 44, no. spe. (2016): 249-95.

Bendiek, A. "European Realism in the EU's Common and Security Foreign Policy". In EU External Relations Law and Policy in the Post-Lisbon Era, edited by J. P. Cardwell, 35-57. The Hague: T. M. C. Asser Press. 2011.

Berman, S. "European disintegration? Warnings from History”. Journal of Democracy 23 , no. 4 (2012): 7-14.

Cárdenas, E. “El nuevo decálogo de la política exterior de Brasil.” La Nación, Mayo 26, 2016. Cervo, L., and A. Lessa. "O declínio: inserção internacional do Brasil (2011-2014)".

Revista Brasileira de Politica Internacional 57, no. 2 (2014): 133-55. doi: https://dx.doi. org/10.1590/0034-7329201400308.

Chryssogelos, A. The EU's crisis of governance and EU foreign policy. London: Chatham House, 2016. Costa Vaz, A. Brazil's strategic partnerships: origins, agendas and outcomes. European Strategic Partnerships Observatory. Madrid: FRID; EGMON, July 2014. Working Paper no. 9. Edler, D., and E. Lanzarou. “The EU and Brazil: A Natural Partnership?”. Alert 5 (2014). European Commission (EU). EU-Brazil Strategic Partnership. Brussels: EU, 2007.

European Commission (EU), and European External Action Service (EEAS). European Union Global Strategy. Brussels: EU, 2016.

European Union (EU). “The Treaty of Lisbon.” last modified September 22, 2015, EUR-Lex, http://eur-lex.europa.eu/legal-content/EN/TXT/?uri=LEGISSUM:ai0033

Ferreira-Pereira, L. C. “The European Union's partnership policy towards Brazil: more than meets the eye". Cambridge Review of International Affairs 29, no. 1 (2016): 55-77. doi: https://doi.org/10.1080/09557571.2015.1103973

Gardini, G. L., and A. Malamud. Debunking Interregionalism: Concepts, Types and CritiqueWith a Transatlantic Focus. Barcelona: CIDOB, 2014. Atlantic Future Working Paper 38. Gratius, S. Can EU Strategic Partnerships deepen multilateralism. Madrid: FRIDE, 2011. Working Paper 109.

Gratius, S. Brazil and the European Union: between balancing and bandwagoning. Madrid: Egmont Institute, FRIDE, 2012. ESPO Working Paper 2. 
Hänggi, H. "Inter-regionalism: empirical and theoretical perspectives." Presentation at the workshop Dollars, Democracy and Trade: External Influence on Economic Integration in the Americas, Los Angeles, CA, May 18, 2000.

Hänggi, H., R. Roloff and J. Rüland, eds. Interregionalism and International Relations: A Stepping Stone to Global Governance?. London: Routledge, 2006.

Hurrell, A. "Hegemony, liberalism and global order: what space for would-be great powers?" International Affairs 82, no. 1 (2006): 1-19. doi: https://doi.org/10.1111/j.14682346.2006.00512.x.

Ikenberry, J. G. “Liberalism in a Realist World.” International Studies 46, no.1-2 (2009): 203-19. doi: https://doi.org/10.1177/002088171004600213.

Malamud, A. "Overlapping Regionalism, No Integration: the Latin American Experiences”. EUI Working Paper RSCAS [Florencia] 20 (2013).

Malamud, C., coord. Relaciones España-Brasil-España. Madrid: Real Instituto Elcano, 2014. Informe 16.

Marks, G., and L. Hooghe. "European Integration from the 1980s: State-Centric v. Multilevel Governance." Journal of Common Market Studies 34, no. 3 (1996): 341-78. doi: http://dx.doi.org/10.1111/j.1468-5965.1996.tb00577.x.

Maull, H. W. "Germany and Japan: the new civilizan powers." Foreign Affairs 69 (1990/1991): 91-106.

Mello, E., and M. Spektor. "How to fix Brazil: Breaking an Addiction to Bad Governmnent". Foreign Affairs 95, no. 5 (2016): 102-10.

Merke, F. "Identidad y política exterior. La Argentina y Brasil en perspectiva histórica.” Sociedad Global 2 no. 2-3 (2008). Accessed October 4, 2017. http://www.eumed.net/ $\mathrm{rev} / \mathrm{sg} / 02 / \mathrm{fm} . \mathrm{htm}$

Ministério das Relaçóes Exteriores. Countries and entities with which Brazil maintains diplomatic relations: Federal Republic of Germany. Brasília, DF: Itamaraty, [n.d.]. http:// www.itamaraty.gov.br/en/ficha-pais/6014-federal-republic-of-germany

Missiroli, A., ed. Towards an EU Global Strategy: Background, process, references. Paris: European Union Institute for Security Studies, 2015.

Molina, I. ¿Y si gana el Brexit en el referéndum? Madrid: Real Instituto Elcano, 2016. ARI 49. Molina, I., and S. Gratius. "Spanien”. In Jahrbuch der Europäischen Integration edited by W. Wessels, and W. Weidenfeld, 577-83. Bonn: Institut für Europäische Politik, 2016.

Moravcsik, A. "Preferences and Power in the European Community: A Liberal Intergovernmentalist Approach.” Journal of Common Market Studies 31, no. 4 (1993): 473-524. doi: http://dx.doi.org/10.1111/j.1468-5965.1993.tb00477.x.

Nye, J. "Will the Liberal Order Survive? The History of an Idea". Foreign Affairs 96, no. spe. (January/February 2017): 10-6.

Putnam, R. D. "Diplomacy and domestic politics: The logic of two-level games". International Organization 42 no. 3 (1988): 427-60. doi: https://doi.org/10.1017/S0020818300027697 
Ribeiro-Hoffmann, A. "Inter- and Transregionalism." In The Oxford Handbook of Comparative Regionalism edited by T. Börzel, and T. Risse, 600-21. Oxford: Oxford University Press, 2016.

Saraiva, M. G. "Brazil's Strategies and Partnerships: The Place of the European Union.” Perspectives 20, no. 2 (2012): 45-62.

Saraiva, M. G. "The Brazil-European Union strategic partnership, from Lula to Dilma Rousseff: a shift of focus”. Revista Brasileira de Politica Internacional 60, no. 1 (2017): e009. doi: http://dx.doi.org/10.1590/0034-7329201600117.

Saraiva, M., and P. A. Velasco Júnior. "A política externa brasileira e o "fim de ciclo" na América do Sul: Para onde vamos?” Pensamiento Propio 21 (2016): 295-324.

Steiner, A. Q., M. A. Medeiros, and R. M. S. Lima. "From Tegucigalpa to Teheran: Brazil's Diplomacy as an emerging Western country". Revista Brasileira de Politica Internacional 57, no. 1 (2014): 40-58. doi: http://dx.doi.org/10.1590/0034-7329201400103.

Stuenkel, O. "Identity and the concept of the West: the case of Brazil and India." Revista Brasileira de Politica Internacional 54, no. 1 (2011): 178-95. doi: http://dx.doi. org/10.1590/S0034-73292011000100011.

Stuenkel, O. "The BRICS and the future of RSP: Was Syria or Libya the Exception." Global Responsibility to Protect 6, no. 1 (2014): 3-28.

Stuenkel, O. "Brazil's top 10 foreign policy challenges in 2017”. Missão Diplomática [blog]. January 8, 2017. http://missaodiplomatica.blogspot.com.es/2017/01/brazils-top-10-foreign-policy.html

Smith, M. "Toward a theory of EU foreign policy-making: multi-level governance, domestic politics, and national adaptation to Europe's common foreign and security policy”. Journal of European Public Policy 11, no. 4 (2004): 740-758. doi: https://doi.org/10.1080/1350176042000248124.

Tepperman, J. "Brazil's Anti-poverty Breakthrough: The Surprising Success of Bolsa Família”. Foreign Affairs 95, no. 1 (January/February 2016).

Tocci, N. The European Union as a normative foreign policy actor. Brussels: CEPS, 2008. Trinkunas, H. What Brazil contributes to the international liberal order. Washington, D.C. Brookings Institute, 2016.

Vaillant, M., and P. Vaillant. "European Union-MERCOSUR Negotiations: A Return to Uncertainties. Latin American Business Review 15, no. 3-4 (2014): 337-62. doi: https://doi.org/10.1080/10978526.2014.931795.

Weyland, K. "Realism under Hegemony: Theorizing the Rise of Brazil”. Journal of Politics in Latin America 8, no. 2 (2016): 143-73.

Womack, B. Asymmetry and International Relationships. Cambridge: Cambridge University Press, 2016. 